\title{
Mótefni bundin við rauðkorn nýbura; orsakir og klínískar afleiðingar Tilfelli greind í Blóðbankanum 2005-2012
}

\author{
Pórdís Kristinsdóttir ${ }^{1}$ læknanemi, Sveinn Kjartansson² læknir, Hildur Harðardóttir ${ }^{1,3}$ læknir, Porbjörn Jónsson ${ }^{4}$ læknir,
} Anna Margrét Halldórsdóttir ${ }^{4}$ læknir

\section{ÁGRIP}

Inngangur: Fóstur- og nýburablóðrof stafar af eyðingu fósturrauð̌korna vegna rauðkornamótefna móður. Rofið getur leitt til blóðleysis og fósturbjúgs á fósturskeiði og gulu hjá nýburum. Prófið Direct Antiglobulin Test (DAT) greinir mótefni bundin við rauð̌korn og er hluti af greiningarferli rofsins. Á Íslandi er DAT gert á naflastrengs-/blóðsýnum nýbura ef móðir er RhD-neikvæð eða hefur rauð̌kornamótefni önnur en anti-A/-B. Markmið rannsóknarinnar var að rannsaka orsakir og afleiðingar jákvæð̌s DAT hjá nýburum á Íslandi á 8 ára tímabili.

Efniviður og aðferðir: Rannsóknarhópurinn var nýburar með jákvætt DAT á árunum 2005-2012. Úr tölvukerfi Blóðbankans voru sóttar upplýsingar um blóðflokk móður og barns, blóđgjafir og DAT. Úr mæðraskrá fengust upplýsingar um fæðingarpyngd, meðgöngulengd og ljósameðferð. Úr rafrænu sjúkraskrárkerfi Landspítala fengust upplýsingar um meðferð og afdrif nýbura.
Niðurstöður: Á árunum 2005-2012 greindust 383 nýburar með jákvætt DAT á Landspítala. Í 73,6\% tilvika var orsökin ABO-blóðflokkamisræmi á milli móður og barns, hjá 20,4\% voru rauð̌kornamótefni móður önnur en anti A/-B, hjá 3,9\% hvort tveggja, en hjá $2,1 \%$ var orsök óljós. Alls fengu 179 (47,6\%) börn meðferð vegna jákvæðs DAT með nýburagulu, par af 167 (93,3\%) ljósameðferð eingöngu. Átta nýburar purftu blóðskiptameðferð, par af 5 vegna Rhesus-mótefna en prjú vegna ABO-blóđflokkamisræmis. Ályktun: Jákvætt DAT hjá nýburum á Íslandi árin 2005-2012 stafađi i flestum tilvikum af ABO-blóðflokkamisræmi á milli móður og barns. Tæplega helmingur barnanna purfti meðhöndlun en oftast nægði ljósameðferð. Í alvarlegustu tilfellum $\mathrm{ABO}$-blóðflokkamisræmis eða rauðkornamótefna annarra en anti-A/-B var pörf á blóðgjöf eða blóðskiptameðferð.
1 ræknadeild Háskóla Íslands, ${ }^{2}$ barnadeild, ${ }^{3}$ kvennadeild, ${ }^{4}$ Blóðbanka Landspítala.

Fyrirspurnir: Anna Margrét Halldórsdóttir, annamha@landspitali.is 23. október 2015, sambykkt til birtingar

13. maí 2016.

Höfundar hafa útfyllt eyðublað um hagsmunatengsl.

\section{Inngangur}

Blóðflokkar byggja á mismunandi samsetningu mótefnisvaka á rauðum blóðkornum. Nú eru pekktir um 300 mismunandi blóðflokkamótefnisvakar sem tilheyra 30 blóðflokkakerfum en af peim eru ABO- og Rhesuskerfin best pekkt og mikilvægust varðandi blóðgjöf. ${ }^{1}$ ABO-blóðflokkakerfið samanstendur af tveimur ríkjandi mótefnisvökum (A og B) sem tvö ósamgena sykruensím mynda, en óvirk ensím einkenna blóðflokk O. Almennt eru anti-A og/eða anti-B mótefni í sermi til staðar gegn framandi A og/eða B mótefnisvaka frá priggja til 6 mánaða aldurs. ${ }^{2}$ Meginhluti anti-A og anti-B eru IgM-mótefni en ABO-blóðflokkamisræmi veldur aðeins vandamálum hjá fóstri ef móðir hefur háan styrk IgG anti-A og/eða anti-B mótefna og eru pað helst mæður í O-blóðflokki. ${ }^{3}$ Ólíkt ABO eru mótefnisvakar flestra annarra blóðflokkakerfa fjölpeptíð en ekki sykrur, til dæmis Rhesus, Kell, Kidd og fleiri. Mótefni gegn fjölpeptíðamótefnisvökum eru ekki til staðar frá náttúrunnar hendi en myndast nær eingöngu eftir næmingu, til dæmis við blóðgjöf eða á meðgöngu. ${ }^{4}$

Fóstur- og nýburablóðrof (Hemolytic disease of the fetus and newborn, FNB) stafar af eyðingu rauðkorna fósturs/nýbura vegna mótefna frá móður með tilheyrandi blóðleysi og/eða hækkun bilirúbíns hjá fóstri/ barni. Alvarlegustu afleiðingar FNB eru fósturbjúgur á meðgöngu (hydrops fetalis) og kjarnagula (kernicterus) hjá nýbura. ${ }^{5}$ Um miðja síðustu öld var FNB algengur sjúkdómur og fyrir árið 1945 létust 50\% allra fóstra sem voru með sjúkdóminn. ${ }^{6}$ Eftir að orsök sjúkdómsins varð ljós urðu miklar framfarir í meðferð og mæðravernd ${ }^{7}$ og nú eru alvarlegir fylgikvillar og dauðsföll af völdum FNB og kjarnagulu sjaldséð á Íslandi.

Lengst af voru mótefni gegn Rhesus $\mathrm{D}$ (RhD) mótefnisvaka á rauðkornum fósturs algengasta orsök FNB, en með tilkomu fyrirbyggjandi meðferðar gegn myndun anti-D ónæmisglóbúlíns er ABO-blóðflokkamisræmi nú algengasta orsökin á Vesturlöndum. ${ }^{6,8}$ Mótefnaskimun í meðgöngu og fyrirbyggjandi meðferð með Rhesus D ónæmisglóbúlíni (RhIg) var innleidd á Íslandi árið 1969 (Rhesus varnir) ${ }^{9}$ og beinist að RhD-neikvæðum konum eftir fæðingu RhD-jákvæðs barns og ef hætta er á að blóðblöndun hafi orðið milli móður og fósturs í meðgöngu, til dæmis eftir fósturlát, legvatnsástungu eða áverka. Víða í nágrannalöndum okkar fá allar RhD-neikvæðar mæður auk pess RhIg á síðasta priðjungi meðgöngu í fyrirbyggjandi skyni. ${ }^{10}$

Skimunarprófið Direct antiglobulin test (DAT, einnig kallað Coombs-próf) greinir mótefni bundin við rauð blóðkorn. ${ }^{11}$ Notkun pess var fyrst lýst af Coombs og félögum árið 1946. ${ }^{12}$ Á Íslandi er DAT gert á nafla- 
Tafla I. Fjöldi og niðurstöður allra DAT-prófa sem gerð voru á árunum 20052012.

\begin{tabular}{ccccc}
\hline Ár & $\begin{array}{c}\text { Jákvæð } \\
\text { (fjöldi barna) }\end{array}$ & Neikvæð & Alls & $\begin{array}{c}\text { Hlutfall } \\
\text { jákvæð (\%) }\end{array}$ \\
\hline 2005 & $51(40)$ & 729 & 780 & 6,5 \\
\hline 2006 & $62(50)$ & 851 & 913 & 6,8 \\
\hline 2007 & $50(43)$ & 822 & 872 & 5,7 \\
\hline 2008 & $63(56)$ & 982 & 1045 & 6,0 \\
\hline 2009 & $59(50)$ & 963 & 1022 & 5,8 \\
\hline 2010 & $71(57)$ & 785 & 856 & 8,3 \\
\hline 2011 & $46(38)$ & 762 & 808 & 5,7 \\
\hline 2012 & $58(49)$ & 741 & 799 & 7,3 \\
\hline Alls & $460(383)$ & 6635 & 7095 & 6,5 \\
\hline
\end{tabular}

strengsblóði frá öllum nýburum RhD-neikvæðra mæðra og einnig nýburum kvenna sem greinst hafa með klínískt mikilvæg rauðkornamótefni á meðgöngu. Einnig er DAT gert á blóðsýni úr nýbura í völdum tilfellum, til staðfestingar á jákvæðu prófi eða til greiningar ef naflastrengssýni var ekki rannsakað. Prófið hefur mikið gildi fyrir rannsóknir á mótefnamiðluðu blóðrofi í nýburum og börn með jákvætt DAT fá almennt meðferð við nýburagulu við lægri skilmerki en önnur. ${ }^{13}$ Ekki fá pó allir nýburar með jákvætt próf klíníska gulu og jákvætt DAT telst áhættupáttur fyrir FNB en ekki örugg greining. ${ }^{14}$ Hafi móðir fengið RhIg-gjöf á meðgöngu greinast allt að $15 \%$ nýbura með jákvætt próf vegna flutnings mótefna yfir fylgju. ${ }^{15}$

Markmið pessarar rannsóknar var að kanna algengi jákvæðs DAT-prófs hjá nýburum á Landspítala á árunum 2005-2012, orsakir og klínískar afleiðingar fyrir fóstur/nýbura. Pessum upplýsingum hefur ekki verið safnað áður hér á landi.

\section{Efniviður og aðferðir}

Rannsóknin var afturskyggn og lýsandi. Tilskilin leyfi fengust frá Siðanefnd Landspítalans (nr. 41/2012), framkvæmdastjóra lækninga á LSH og Persónuvernd (nr. 2012111300HGK). Niðurstöður voru unnar úr gögnum frá tölvukerfi Blóðbankans (ProSang), úr rafrænu sjúkraskárkerfi Landspítalans (Sögu) og pappírsskrám frá Blóðbanka, Barnaspítala Hringsins og kvennadeild Landspítalans.

Rannsóknarhópurinn var nýburar sem greindust með jákvætt DAT samkvæmt gögnum Blóðbankans á 8 ára tímabili, 2005-2012. Nýburar voru skilgreindir sem börn yngri en eins mánaðar gömul. Skrá yfir öll DAT-próf sem voru framkvæmd í Blóðbankanum á pessu ákveðna tímabili var unnin úr tölvukerfi Blóðbankans (ProSang). Einstaklingar sem ekki töldust nýburar eða voru með neikvætt DAT voru útilokaðir frá rannsókninni. Úr ProSang fengust einnig upplýsingar um blóðflokk, dagsetningar prófs, líklega orsök jákvæðs prófs og hvort einstaklingar hefðu fengið blóðgjöf eða -skipti. Til pess að sannreyna áreiðanleika tölvugagna voru niðurstöður DAT fyrir árin 2010-2012 borin saman við pappírsskrár Blóðbankans.

Nafni og kennitölu móður hvers nýbura var flett upp í Pjóðskrá. Úr tölvukerfi Blóðbankans fengust upplýsingar um blóðflokk móður, rauðkornamótefni og blóðinngjafir fyrir meðgöngu.
Tafla II. ABO-blóðflokkur móður og barns í rannsóknarhópnum.

\begin{tabular}{c|cccccc}
\hline ABO blóðflokkur barns & \multicolumn{6}{|c}{ ABO blóðflokkur móður } \\
\hline & $\mathrm{A}$ & $\mathrm{AB}$ & $\mathrm{B}$ & $\mathrm{O}$ & $\mathrm{X}^{*}$ & Alls \\
\hline $\mathrm{A}$ & 17 & 0 & 1 & 218 & 1 & 237 \\
\hline $\mathrm{AB}$ & 2 & 0 & 3 & 0 & 0 & 5 \\
\hline $\mathrm{B}$ & 0 & 0 & 2 & 59 & 1 & 62 \\
\hline $\mathrm{O}$ & 3 & 0 & 4 & 19 & 0 & 26 \\
\hline $\mathrm{X}^{\star}$ & 13 & 1 & 4 & 35 & 0 & 53 \\
\hline Alls & 35 & 1 & 14 & 331 & 2 & 383 \\
\hline *blóðflokkur ópekktur & & & & & &
\end{tabular}

*blóðflokkur ópekktur

Úr mæðraskrám og barnablöðum einstaklinga í úrtakinu voru skráðar upplýsingar um meðgöngulengd, fæðingarpyngd, fæðingarmáta, ljósameðferð og bilirúbín-blóðgildi. Frekari upplýsingar um meðferð og afdrif barna fengust úr rafrænu sjúkraskrárkerfi Landspítalans.

Úr Landsskrá fæðinga fengust upplýsingar um fjölda fæðinga á kvennadeild Landspítala á rannsóknartímabilinu. Upplýsingar um fjölda fæðinga á Íslandi pau ár sem rannsóknin náði til voru fengnar á vef Hagstofu Íslands.

Upplýsingar voru skráđar í Excel-töflureikni sem var notaður við úrvinnslu, uppsetningu gagna og útreikninga. Niðurstöður eru birtar sem meðaltöl \pm staðalfrávik (miðgildi, spönn) nema annað sé tekið fram. Samanburður á milli hópa var gerður með ópöruðu t-prófi fyrir samfelldar breytur og Fisher's exact prófi fyrir nafnabreytur.

\section{Niðurstöður}

Rannsóknarhópinn mynduðu 383 nýburar sem fæddust á árunum 2005-2012 og voru með jákvætt DAT samkvæmt skráningu í tölvukerfi Blóðbankans, 194 drengir (50,6\%) og 189 stúlkur (49,4\%). Stærsti hluti hópsins fæddist á fæðingadeild Landspítala en 11 nýburar fæddust utan höfuðborgarsvæðisins. Meðgöngulengd var að meðaltali $276 \pm 15$ dagar (miðgildi 279, spönn 167-296 dagar), eða að meðaltali 39 vikur og 3 dagar \pm 2 vikur og 1 dagur (39 vikur og 5 dagar, frá 23 vikum og 6 dögum til 42 vikna og 2 daga). Fæðingarpyngd var $3495 \pm 615$ g (3523 g, 585-5345 g). Í hópnum fæddust 270 (70,5\%) um leggöng, 79 (20,6\%) með keisaraskurði, 31 $(8,1 \%)$ með hjálp sogklukku/tangar en prjú börn $(0,8 \%)$ voru andvana fædd. Andlát peirra voru ótengd mótefnamyndun en eitt peirra lést vegna sýkingar, hjá öðru var naflastrengur vafinn um háls og hjá pví priðja var dánarorsök óljós. Fjöldi mæðra var 344; tvær konur áttu prjú börn, 37 áttu tvö börn og 303 áttu eitt barn í rannsóknarhópnum.

Samtals voru gerð 7095 DAT-próf á nýburum á rannsóknartímabilinu, eða á bilinu 780-1045 árlega (tafla I). Af pessum 7095 prófum reyndust 460 vera jákvæð (6,5\%). Pessi 460 próf voru gerð á 383 börnum, en fyrir 77 peirra voru gerð tvenn próf, pað seinna til staðfestingar á pví fyrra. Prófið var ýmist gert á naflastrengsblóðsýni eða blóðsýni úr nýbura, og stundum hvoru tveggja. Fyrsta jákvæða DAT-próf var í 219 tilfellum (57,2\%) naflastrengssýni (59 síðar staðfest með blóðsýni) og í 164 tilfellum (42,8\%) blóðsýni (18 síðar staðfest með öðru blóðsýni). 
Tafla III. Orsök jákvæðra DAT-prófa hjá nýburum árin 2005-2012.

\begin{tabular}{cccccc}
\hline Ár & $\begin{array}{c}\text { Rauðkorna- } \\
\text { mótefni } \\
\text { gegn A } \\
\text { eða B }\end{array}$ & $\begin{array}{c}\text { Önnur } \\
\text { rauðkorna- } \\
\text { mótefni } \\
\text { en anti-A/-B }\end{array}$ & $\begin{array}{c}\text { Bæði anti-A/-B } \\
\text { og önnur } \\
\text { rauðkorna- } \\
\text { mótefni }\end{array}$ & $\begin{array}{c}\text { Orsök } \\
\text { óljós }\end{array}$ & $\begin{array}{c}\text { Heildar- } \\
\text { fjöldi }\end{array}$ \\
\hline 2005 & 35 & 4 & 1 & 0 & 40 \\
\hline 2006 & 32 & 11 & 4 & 2 & 49 \\
\hline 2007 & 30 & 10 & 1 & 3 & 44 \\
\hline 2008 & 41 & 12 & 3 & 0 & 56 \\
\hline 2009 & 36 & 12 & 1 & 1 & 50 \\
\hline 2010 & 41 & 14 & 1 & 1 & 57 \\
\hline 2011 & 29 & 7 & 1 & 1 & 38 \\
\hline 2012 & 38 & 8 & 3 & 0 & 49 \\
\hline Alls & 282 & 78 & 15 & 8 & 383 \\
\hline
\end{tabular}

Í langflestum tilfellum (86,4\%) var móðir barna í rannsóknarhópi í O-blóðflokki (tafla II). Algengasta blóðflokkasamsetningin var móðir í blóðflokki O sem gekk með barn í blóðflokki A (56,9\%) en næstalgengast var móðir í flokki O sem gekk með barn í flokki B (15,4\%). Í 53 tilfellum hafði ekki tekist að blóðflokka barn pegar DAT var gert og í tveimur tilvikum var blóðflokkur móður ópekktur. DAT á naflastrengssýni er staðalrannsókn hjá nýburum RhD-neikvæðra mæðra og mæðra með rauðkornamótefni önnur en anti-A/-B á meðgöngu. Í rannsóknarhópnum var um helmingur (51,4\%) mæðranna RhD-neikvæður, tæpur priðjungur $(29,0 \%)$ mæðranna hafði pekkt rauðkornamótefni önnur en anti-A/-B á meðgöngu en 16,2\% voru bæði RhD-neikvæðar og með rauðkornamótefni önnur en anti-A/-B. Hjá rúmum priðjungi hópsins (35,3\%) voru mæður hvorki RhD-neikvæðar né með pekkt rauðkornamótefni önnur en anti-A/-B.

Í langflestum tilfellum, alls 282 (73,6\%), var líkleg orsök jákvæðs DAT ABO-misræmi á milli móður og barns (tafla III). Í 78 (20,4\%) tilfella var orsökin rauðkornamótefni önnur en anti-A/-B hjá móður, hjá 15 (3,9\%) var um að ræða bæði ABO-misræmi og rauðkornamótefni önnur en anti-A/-B, en hjá 8 börnum, eða 2,1\%, var orsök ópekkt. Í öllum peim 15 tilfellum par sem bæði var um ABO-misræmi og rauðkornamótefni önnur en anti-A/-B að ræða var mótefnið með sértækni gegn Rhesus-mótefnavaka (10 með

Tafla IV. Meðhöndlun nýbura með jákvætt DAT-próf á rannsóknartímanum.

\begin{tabular}{cccccc}
\hline Ár & $\begin{array}{c}\text { Ljósa- } \\
\text { meðferð }\end{array}$ & $\begin{array}{c}\text { Blóð- } \\
\text { gjöf }\end{array}$ & $\begin{array}{c}\text { Blóð- } \\
\text { skipti }\end{array}$ & Engin & $\begin{array}{c}\text { Hlutfall barna } \\
\text { sem fékk meðferð (\%) }\end{array}$ \\
\hline 2005 & 19 & 0 & 0 & 21 & 47,5 \\
\hline 2006 & 24 & 1 & 1 & 24 & 50,0 \\
\hline 2007 & 22 & 0 & 4 & 20 & 52,4 \\
\hline 2008 & 27 & 1 & 1 & 29 & 48,2 \\
\hline 2009 & 27 & 1 & 2 & 21 & 56,3 \\
\hline 2010 & 30 & 1 & 0 & 27 & 52,6 \\
\hline 2011 & 14 & 0 & 0 & 24 & 36,8 \\
\hline 2012 & 15 & 1 & 0 & 31 & 34,0 \\
\hline Alls & 178 & 5 & 8 & 197 & 47,6 \\
\hline
\end{tabular}

Mynd 1. Sértækni rauðkornamótefna annarra en anti-A/-B pegar aðeins eitt mótefni var til staðar hjá móður nýbura með jákvætt DAT-próf.

anti-D, 5 með anti-E). Í peim tilfellum par sem um anti-D, auk anti-A/-B, var að ræða hafði móðir fengið fyrirbyggjandi RhIg á meðgöngu. Í peim tilfellum par sem móðir myndaði bæði anti-A og anti-E var ýmist talið að jákvætt próf væri vegna anti-A (n=1) eða vegna anti-E $(n=4)$. Pegar ABO-blóðflokkamisræmi olli jákvæðu DAT var algengast að móðir í blóðflokki O gengi með barn í blóðflokki A, en sú var raunin í 203 (72,0\%) tilfella. Í 59 (20,9\%) tilfella var móðir í blóðflokki O og barn í blóðflokki B. Samtals var móðir í blóðflokki O í 98,2\% allra tilfella par sem jákvætt DAT stafaði af ABO-misræmi. Í peim premur tilfellum sem móðir var ekki í blóðflokki O var barnið í blóðflokki AB.

Rauðkornamótefni frá móður, önnur en anti-A/-B, voru orsök jákvæðs DAT hjá 78 nýburum á tímabilinu. Tíu mæður áttu tvö börn í pessum hópi svo fjöldi mæðra með rauðkornamótefni önnur en anti-A/-B var 68. Hjá 39 börnum greindist aðeins eitt mótefni hjá móður, hjá 32 greindust tvö mótefni, en prjú eða fjögur mótefni greindust í 7 tilfellum. Par sem eitt mótefni greindist var oftast um anti-D ( $\mathrm{n}=24,61,5 \%)$ að ræða en næstalgengasta staka mótefnið var anti-E ( $n=8,20,5 \%)$ (mynd 1). Algengasta samsetning pegar um mótefni gegn tveimur mótefnavökum var að ræða var anti-c með anti-E ( $n=18)$, eða anti-c með anti-D ( $n=5)$, en aðrar samsetningar voru sjaldgæfari. Hjá 7 nýburum greindust prjú eða fjögur mótefni í 6 mismunandi samsetningum, en anti-D var til staðar hjá öllum nema einu tilfelli. Af 68 mæðrum með rauðkornamótefni önnur en anti-A/-B höfðu 15 (22,1\%) fengið blóðgjöf fyrir meðgöngu. Mæður nýbura með jákvætt DAT af öðrum sökum (til dæmis ABO-misræmi) höfðu marktækt sjaldnar fengið blóðgjöf fyrir meðgöngu, eða 13 af 276 konum (4,7\%) (P<0,0001). Í 5 af 7 tilfellum $(71,4 \%)$ par sem fleiri en eitt rauðkornamótefni önnur en anti-A/-B greindust hafði móðir fengið blóðgjöf fyrir meðgöngu.

Í engri meðgöngu í pessari rannsókn var framkvæmd blóðgjöf til fósturs um naflastreng vegna teikna um alvarlegt blóðrof. Nægilegar upplýsingar um meðferð nýbura voru til staðar fyrir 376 börn af 383 í rannsóknarhópnum en af peim fengu 179 (47,6\%) einhvers konar meðferð yfir rannsóknartímabilið (tafla IV). Hefðbundin meðferðarúrræði eru ljósameðferð, blóðgjöf og blóðskipti. Algengasta meðferðin var ljósameðferð og var hún veitt 178 börnum (47,3\%), en af peim fengu prjú börn til viðbótar blóðgjöf, 
Tafla V. Nýburar í rannsóknarhópnum sem voru meðhöndlaðir með blóðskiptameðferð.

\begin{tabular}{|c|c|c|c|c|c|c|c|c|c|}
\hline \multirow[t]{2}{*}{ Tilfelli } & \multirow[t]{2}{*}{ Fæðingarár } & \multirow{2}{*}{$\begin{array}{l}\text { Rauókorna- } \\
\text { mótefni }\end{array}$} & \multirow{2}{*}{$\begin{array}{l}\text { Meðgöngu- } \\
\text { lengd (dagar) }\end{array}$} & \multicolumn{2}{|c|}{ Serum bílirúbin ( $\mu \mathrm{mol} / \mathrm{L})$} & \multicolumn{2}{|c|}{ Ljósameðferð } & \multirow{2}{*}{ Blóðgjöf } & \multirow{2}{*}{$\begin{array}{c}\text { Blóðskipti } \\
\text { Aldur barns }{ }^{\star \star}\end{array}$} \\
\hline & & & & Hæsta gildi & Aldur barns ${ }^{\star}$ & Aldur barns ${ }^{\star *}$ & Lengd (dagar) & & \\
\hline 1 & 2006 & Anti-c, E & 266 & 252 & 1 & 0 & 4 & nei & 1 \\
\hline 2 & 2007 & Anti-D & 256 & 161 & 0 & 1 & 4 & nei & 1 \\
\hline 3 & 2007 & Anti-A & 281 & 420 & 3 & 3 & 4 & nei & 3 \\
\hline 4 & 2007 & Anti-D & 265 & 300 & 1 & 1 & 5 & nei & 1 \\
\hline 5 & 2007 & Anti-B & 276 & 317 & 1 & 1 & 2 & nei & 1 \\
\hline 6 & 2008 & Anti-B & 287 & 393 & 1 & 1 & 3 & nei & 1 \\
\hline 7 & 2009 & Anti-D & 273 & 326 & 2 & 2 & 4 & já & 2 \\
\hline 8 & 2009 & Anti-D & 273 & 235 & 0 & 1 & 4 & nei & 1 \\
\hline
\end{tabular}

*Aldur barns í dögum eftir fæðingu pegar hæsta gildi bilirúbíns mældist. *^Aldur barns í dögum eftir fæðingu við upphaf meðferðar.

sjö einnig blóðskipti og eitt barn fékk allt prennt; ljósameðferð, blóðgjöf og blóðskipti. Orsök jákvæðs DAT hjá peim 168 börnum sem fengu eingöngu ljósameðferð var í 79,6\% tilvika ABO-blóðflokkamisræmi en rauðkornamótefni önnur en anti-A/-B í 18,6\% tilvika. Hæsta gildi serum bilirúbíns fyrir eða á meðan ljósameðferð stóð var skráð fyrir 162 börn og var að meðaltali $245 \mu \mathrm{mol} / \mathrm{L}$ $\pm 70 \mu \mathrm{mol} / \mathrm{L}(251 \mu \mathrm{mol} / \mathrm{L}, 91-465 \mu \mathrm{mol} / \mathrm{L})$. Hæsta gildi mældist á fyrsta til 10. sólarhring eftir fæðingu en oftast eftir tvo sólarhringa. Ljósameðferð hófst oftast eftir einn $(n=63)$ eða tvo $(n=46)$ sólarhringa frá fæðingu en í sumum tilfellum strax á fyrsta sólarhring (n=22). Börn með jákvætt DAT vegna rauðkornamótefna annarra en anti-A/-B fengu marktækt lengri ljósameðferð en börn með ABO-misræmi sem orsök jákvæðs prófs (3,1 $\pm 2,1$ dagar á móti $2,4 \pm 1,3, \mathrm{P}<0,05)$.

Alls fengu 12 börn blóðgjöf en af peim fengu 7 börn blóð vegna annarra ástæðna en blóðrofs, svo sem vegna skurðaðgerða eða tíðrar blóðsýnatöku og falla pau ekki undir pennan flokk. Á tímabilinu fengu pví 5 börn blóðgjöf vegna FNB. Prjú börn höfðu mótefni gegn RhD, eitt gegn c/E og eitt hafði anti-B. Öll börn fyrir utan eitt fengu ljósameðferð fljótlega eftir fæðingu en purftu síðar blóðgjöf vegna lágs blóðrauðagildis við tveggja til fjögurra vikna aldur.

Alls fengu 8 börn í rannsóknarhópnum blóðskiptameðferð (tafla V) og voru pau öll fædd á árunum 2006-2009. Um var að ræða ABO-blóðflokkamisræmi hjá premur nýburum en Rhesus- rauðkornamótefni hjá 5 . Vitað var um mótefnamyndun á meðgöngu hjá pessum 5 mæðrum og voru pær í viðeigandi eftirliti. Hjá premur greindist marktæk hækkun á mótefnastyrk á meðgöngu (tilfelli \#1, \#2 og \#7) en ekki hjá hinum tveimur (tilfelli \#4 og \#8). Hjá mæðrum priggja barna (tilfelli \#2, \#4 og \#7) var fæðing framkölluð vegna teikna um blóðrof hjá fóstri. Hjá einni var framkölluð fæðing vegna gallteppu, eitt barn fæddist með bráðakeisaraskurði vegna tepptra hríða af völdum misræmis fósturs og grindar, en prjú fæddust með eðlilegri fæðingu. Öll börnin fóru í ljósameðferð fyrir og/eða eftir blóðskiptin.

Af nýburum með jákvætt DAT vegna rauðkornamótefna annarra en anti-A/-B fengu 52,6\% meðferð en 49,1\% peirra par sem um ABO-blóðflokkamisræmi var að ræða. Hlutfallslega fleiri fengu meðferð vegna anti-B (62,9\%) en vegna anti-A $(45,2 \%)$ $(\mathrm{P}<0,05)$. Meðgöngulengd við fæðingu var marktækt styttri $(272,3$ $\pm 18,4$ á móti $279,9 \pm 10,0$ dagar) og fæðingarpyngd lægri (3390,9 $\pm 654,9$ á móti $3586,4 \pm 573,2$ g) hjá nýburum sem fengu meðferð samanborið við pá sem ekki fengu meðferð $(\mathrm{P}<0,001)$. Eins og áður segir fékk ekkert fóstur blóðgjöf um naflastreng (intrauterine transfusion) í rannsóknarhópnum á rannsóknartímabilinu.

\section{Umræða}

Hlutfall jákvæðra DAT-prófa hjá nýburum á tímabilinu var 6,5\%. Petta hlutfall er litlu lægra en í rannsókn sem gerð var árið 2000 í Kaliforníu, en par var hlutfall jákvæðra prófa 7,9\%.16 Í peirri rannsókn var DAT gert hjá börnum allra kvenna sem voru í blóðflokki O eða voru RhD-neikvæðar. Hér á landi er venjan að gera DAT ef móðir er RhD-neikvæð eða ef rauðkornamótefni önnur en anti-A/-B hafa greinst hjá móður á meðgöngu. Áhugavert er að hlutfall jákvæðra prófa var hærra í Kaliforníu par sem skilyrði fyrir framkvæmd prófs eru rýmri en hér á landi. Sú staðreynd að algengasta ástæða jákvæðs DAT-prófs í pessu rannsóknarpýði var ABO-blóðflokkamisræmi gæti bent til vangreiningar á jákvæðu DAT vegna ABO-misræmis á Íslandi par sem ekki er reglan að prófa nýbura allra mæðra í blóðflokki O. Í annarri rannsókn sem gerð var á Nýja-Sjálandi árið 2001 á 660 nýburum höfðu aðeins 3,5\% jákvætt DAT. ${ }^{14}$ Lægra hlutfall jákvæðra prófa í peirri rannsókn má líklega skýra með pví að par var DAT gert hjá öllum nýburum sem lagðir voru inn á sængurdeild, óháð blóðflokkasamsetningu móður og barns.

Rhesus-varnir hafa fækkað til muna meðgöngum með anti-D mótefnamyndun bæði hérlendis og erlendis. Rannsókn á greiningum blóðflokkamótefna í meðgöngu á Íslandi árin 1970-1984 sýndi greinilega lækkun á tíðni anti-D-mótefnamyndunar hjá Rhesus D-neikvæðum konum á rannsóknartímanum. ${ }^{9}$ Í okkar rannsóknarhóp greindist pó anti-D mótefni í 46,2\% tilfella par sem jákvætt DAT stafaði af rauðkornamótefni öðru en anti-A/-B. Petta er talvert hærra hlutfall anti-D mótefna en í Bandaríkjunum par sem ráðlagt er að gefa öllum RhD-neikvæðrum mæðrum fyrirbyggjandi RhIg bæði á síðasta priðjungi meðgöngu og eftir fæðingu' ${ }^{8}$. Petta vekur upp pá spurningu hvort rétt væri að taka upp sams konar stefnu og í Bandaríkjunum, Bretlandi og víðar og gefa reglubundið RhIg á miðri meðgöngu í peim tilgangi að lækka tíðni anti-D mótefnamyndunar. Sú ráđstöfun myndi reyndar líklega leiða til fjölgunar á falsk-jákvæðum DAT-prófum samkvæmt nýlegri rannsókn frá Ástralíu. Innleiðing reglubundins fyrirbyggjandi RhIg á 
meðgöngu í peirri rannsókn fjölgaði jákvæðum DAT- prófum nýbura umtalsvert og var skýringin talin óvirkur flutningur anti-D mótefnis yfir fylgju til fósturs. ${ }^{17}$

Áhugavert var að yfir 20\% mæðra nýbura með jákvætt DATpróf vegna rauðkornamótefna annarra en anti-A/-B höfðu fengið blóðgjöf fyrir meðgöngu en aðeins tæp 5\% mæðra annarra barna í rannsókninni. Petta kemur heim og saman við pá staðreynd að pótt parað sé fyrir helstu mótefnisvökum við blóðgjöf getur næming fyrir öðrum mótefnisvökum átt sér stað. ${ }^{18}$ Anti-Kell (K) er sérstakt í pessu samhengi en bandarísk rannsókn sýndi að 2/3 kvenna með pað mótefni höfðu sögu um fyrri blóðgjöf..$^{19}$ Í okkar rannsókn hafði aðeins ein af fjórum konum með Kell-mótefni sögu um blóðgjöf, en lægra hlutfall má skýra með pví að hér á landi er konum á barneignaraldri gefið Kell-neikvætt blóð samkvæmt verklagi Blóðbankans. Í ljósi pessara niðurstaðna má velta pví fyrir sér hvort rétt væri að gefa konum á barneignaraldri rauðkornaeiningar sem væru samræmanlegar hvað varðar fleiri mótefnavaka til pess að forðast næmingu gegn peim.

Af peim nýburum sem voru með jákvætt DAT vegna anti-A fengu 45,2\% meðferð en marktækt hærra hlutfall peirra sem voru með anti-B, eða $62,9 \%$. Af peim börnum sem fengu blóðskipti var eitt tilfelli vegna anti-A en tvö vegna anti-B pó svo að 3,5 sinnum fleiri tilfelli ABO-blóðflokkamisræmis hafi greinst hjá börnum í blóðflokki A. Petta bendir til pess að anti-B mótefni hafi almennt alvarlegri afleiðingar í för með sér en anti-A og samrýmist sú ályktun niðurstöðum annarra rannsókna. ${ }^{20}$ Nýburar mæðra með rauðkornamótefni önnur en anti-A/-B fengu marktækt lengri ljósameðferð en aðrir nýburar. Pessi börn voru $80,0 \%$ peirra sem fengu blóðgjöf og 62,5\% peirra sem fóru í blóðskipti, prátt fyrir að vera aðeins 20,4\% alls rannsóknarhópsins. Petta er í samræmi við pá almennu skoðun að ABO-blóðflokkamisræmi valdi vægari tilfellum af FNB samanborið við önnur rauðkornamótefni. ${ }^{5,21}$

Athygli vekur að af peim 8 nýburum sem purftu blóðskipti var jákvætt DAT í premur tilfellum vegna ABO-blóðflokkamisræmis, en eins og áður hefur komið fram er almennt talið að anti-A og anti-B mótefni valdi vægari FNB en Rhesus-mótefni. Hjá pessum premur börnum var DAT ekki gert fyrr en við 1-3 daga aldur en ekki við fæðingu. Hefði DAT verið gert strax eftir fæðingu og hækkun á bilirúbíngildum nýburans greinst í kjölfarið, hefði ljósameðferð getað hafist fyrr og hugsanlega hefði verið komist hjá blóðskiptameðferð. Petta styður pá hugmynd að gera eigi DAT á naflastrengsblóði barna allra kvenna í O-blóðflokki líkt og tíðkast í sumum löndum. ${ }^{22,23}$ Kanadísk rannsókn birt 2006 benti til hárrar tíðni endurinnlagna nýbura vegna gulu og alvarlegs FNB, oftast vegna $\mathrm{ABO}$-misræmis, og að pörf væri á aðgerðum til pess að bæta tímanlega greiningu nýburagulu. ${ }^{24}$ Hins vegar er notkun DAT-prófs á naflastrengsblóði sem skimtæki hjá öllum mæðrum í O-blóðflokki ekki óumdeild par sem pessi aðferð hefur takmarkað forspárgildi fyrir FNB og hefur kostnað í för með sér. ${ }^{25}$ Pó er mikilvægt að koma upp skilvirku kerfi til pess að spá fyrir um og/eða greina snemma nýburagulu af völdum blóðrofs par sem mæður og nýburar eru að jafnaði útskrifuð af fæðingardeild innan við sólarhring frá fæðingu og erfitt getur verið að greina gulu út frá húðlit barnsins eftir útskrift.
Eftir að farið var að nota ljósameðferð í auknum mæli hefur blóðskiptameðferðum fækkað til muna og hafa blóðskipti ekki verið gerð á nýbura hér á landi síðan árið 2009. Hugsanleg skýring er bætt eftirlit á meðgöngu og tímanlegt inngrip ef merki eru um alvarlegt blóðrof. Enn fremur tíðkaðist áður fyrr að meðhöndla börn með alvarlegt blóðrof frekar með blóðskiptum en ljósum, pví blóðskipti minnkuðu áframhaldandi blóðrof og par með líkur á pví að börnin pyrftu blóðgjöf síðar. Hin seinni ár hafa börn með alvarlegt blóðrof hins vegar fremur verið meðhöndluð með kröftugri ljósameðferð og pannig reynt að forðast blóðskipti. Aðrir meðferðarkostir en blóðskipti hafa verið reyndir, og rannsóknir hafa sýnt að fyrirbyggjandi ónæmisglóbúlínmeðferð hjá nýburum með FNB getur dregið úr lengd ljósameðferðar og sjúkrahúsdvalar, pó ekki hafi verið sýnt fram á að slík meðferð dragi úr pörf á blóðskiptameðferð. ${ }^{26,27}$ Einn nýburi með FNB hefur verið meðhöndlaður með háskammta ónæmisglóbúlíni á Íslandi svo vitað sé. Pó fækkun blóðskipta sé vissulega jákvæð próun leiðir hún óhjákvæmilega af sér færri tækifæri til pjálfunar starfsfólks Landspítala í framkvæmd blóðskipta. Með minnkandi reynslu eykst áhættan við meðferð og einnig er hugsanlegt að læknar veigri sér við að beita henni. Ekki eru til íslenskar klínískar leiðbeiningar um blóðskiptameðferð nýbura en erlendar leiðbeiningar eru hafðar til hliðsjónar. Gagnlegt væri að útbúa klínískar leiðbeiningar sem taka mið af fyrri reynslu, aðstæðum og öðrum verklagsreglum hér á landi.

\section{Niðurlag}

Helstu niðurstöður pessarar rannsóknar voru að meirihluti jákvæðra DAT-prófa á árunum 2005-2012 var vegna ABO-blóðflokkamisræmis og nánast helmingur peirra barna purfti meðferð, par af prjú blóðskiptameðferð. Í ljósi pessara niðurstaðna er rétt að hugleiða hvort gera ætti DAT-próf á naflastrengssýnum nýbura allra mæðra í blóðflokki O eða innleiða aðrar aðferðir til pess að greina nýburagulu snemma. Anti-D er algengara á meðgöngu hérlendis en víða erlendis par sem reglubundin gjöf RhIg á meðgöngu hefur verið innleidd. Stefnt er að innleiðingu á fyrirbyggjandi gjöf RhIg á meðgöngu á Íslandi og verður gjöf RhIg stýrt með sameindaerfðafræðilegri greiningu á RhD blóðflokki fósturs með blóðsýni frá móður svo einungis RhD neikvæðar mæður sem ganga með RhD jákvæð fóstur fá RhIg. Blóðskiptameðferðir á nýburum vegna FNB voru fáar á rannsóknartímabilinu og má sennilega rekja pað til bættrar greiningartækni, eftirlits og öflugri ljósameðferðar. Gagnlegt væri að gera séríslenskar klínískar leiðbeiningar um eftirlit og meðferð nýbura sem eiga á hættu á að fá FNB.

\section{Pakkir}

Guðrún Svansdóttir forstöðunáttúrufræðingur í Blóðbankanum og annað starfsfólk Blóðbankans fá sérstakar pakkir fyrir aðstoð við upplýsingaöflun. Starfsfólk skjalageymslu Landspítala í Vesturhlíð fær pakkir fyrir hjálp við leit að sjúkraskrám. Einnig fær Anna Haarde skrifstofustjóri á kvennadeild og starfsfólk kvennadeildar kærar pakkir fyrir veitta aðstoð. 


\section{Heimildir}

1. Poole J, Daniels G. Blood group antibodies and their significance in transfusion medicine. Transfus Med Rev 2007; 21: 58-71.

2. Harmening DM. Modern Blood Banking \& Transfusion Practices. 5th ed. F.A. Davis Company, Fíladelfíu, Bandaríkjunum 2005.

3. Chen JY, Ling UP. Prediction of the development of neonatal hyperbilirubinemia in $\mathrm{ABO}$ incompatibility. Zhonghua Yi Xue Za Zhi (Taipei) 1994; 53: 13-8.

4. Petrides M, Stack G, Cooling L, Maes LY. Practical Guide to Transfusion Medicine. 2nd ed. AABB Pres, Bethesda, Maryland 2007.

5. Murray NA, Roberts IA. Haemolytic disease of the newborn. Arch Dis Child Fetal Neonatal Ed 2007; 92: F83-F88.

6. Bowman J. Thirty-five years of $\mathrm{Rh}$ prophylaxis. Transfusion 2003; 43: 1661-6.

7. Roberts IA. The changing face of haemolytic disease of the newborn. Early Hum Dev 2008; 84: 515-23.

8. Geifman-Holtzman O, Wojtowycz M, Kosmas E, Artal R. Female alloimmunization with antibodies known to cause hemolytic disease. Obstet Gynecol 1997; 89: 272-5.

9. Hellman-Erlingsson S. Greining blóðflokkamótefna hjá vanfærum konum og mæðrum á Íslandi 1970-1984. Læknablaðið 1986; 72: 321-9.

10. Nordvall M, Dziegel M, Hegaard HK, Bidstrup M, Jonsbo F, Christensen B, et al. Red blood cell antibodies in pregnancy and their clinical consequences: synergistic effects of multiple specificities. Transfusion 2009; 9: 2070-5.

11. Dinesh D. Review of positive direct antiglobulin tests found on cord blood sampling. J Paediatr Child Health 2005; 41: 504-7
12. Coombs RRA, Mourant AE, Race RR. In-vivo isosensitisation of red cells in babies with hæmolytic disease. Lancet 1946; 247: 264-6.

13. Pediatrics A.A.o. Clinical practice guideline: management of hyperbilirubinemia in the newborn infant 35 or more weeks of gestation. Pediatrics 2004; 114: 297-316.

14. Herschel M, Karrison T, Wen M, Caldarelli L, Baron B. Evaluation of the direct antiglobulin (Coombs') test for identifying newborns at risk for hemolysis as determined by end-tidal carbon monoxide concentration (ETCOc); and comparison of the Coombs' test with ETCOc for detecting significant jaundice. J Perinatol 2002; 22: 341-7.

15. Cortey A, Brossard Y. [Adverse effects and patient information]. J Gynecol Obstet Biol Reprod (Paris) 2006; 35(1 Suppl): 1S112-1S118.

16. Madan A, Huntsinger K, Burgos A, Benitz WE. Readmission for newborn jaundice: the value of the Coombs' test in predicting the need for phototherapy. Clin Pediatr 2004; 43: 63-8.

17. Dillon A, Chaudhari T, Crispin P, Shadbolt B, Kent A. Has anti-D prophylaxis increased the rate of positive direct antiglobulin test results and can the direct antiglobulin test predict need for phototherapy in $\mathrm{Rh} / \mathrm{ABO}$ incompatibility? J Paediatr Child Health 2011; 47: 40-3.

18. Moise KJ. Fetal anemia due to non-Rhesus-D red-cell alloimmunization. Sem Fetal Neonatal Med 2008; 13: 207-14.

19. McKenna DS, Nagaraja HN, O'Shaughnessy R. Management of pregnancies complicated by anti-Kell isoimmunization. Obstet Gynecol 1999; 93: 667-73.
20. Kaplan M, Hammerman C, Vreman HJ, Wong RJ Stevenson DK. Hemolysis and hyperbilirubinemia in antiglobulin positive, direct $\mathrm{ABO}$ blood group heterospecific neonates. J Pediatr 2010; 157: 772-7.

21. Daniels G, Poole J, De Silva M, Callaghan T, MacLennan $\mathrm{S}$, Smith $\mathrm{N}$. The clinical significance of blood group antibodies. Transfus Med 2002; 12: 287-95.

22. American Academy of Pediatrics Subcommittee on Hyperbilirubinemia. Management of hyperbilirubinemia in the newborn infant 35 or more weeks of gestation Pediatrics 2004; 114: 297-316.

23. Kaplan M, Na'amad M, Kenan A, Rudensky B, Hammerman C, Vreman HJ, et al. Failure to predic hemolysis and hyperbilirubinemia by IgG Subclass in blood group $\mathrm{A}$ or B infants born to group $\mathrm{O}$ mothers. Pediatr 2009; 123: e132-e137.

24. Sgro M, Campbell D, Shah V. Incidence and causes of severe neonatal hyperbilirubinemia in Canada. CMAJ 2006; 175: 587-90.

25. Wainer S, Rabi J, Lyon M. Coombs' testing and neonatal hyperbilirubinemia. CMAJ 2007; 176: 972-3; author reply 973.

26. Elalfy MS, Elbarbary NS, Abaza HW. Early intravenous immunoglobin (two-dose regimen) in the management of severe $\mathrm{Rh}$ hemolytic disease of newborn--a prospective randomized controlled trial. Eur J Pediatr 2011; 170: 461-7.

27. Smits-Wintjens VE, Walther FJ, Rath ME, Lindenburg IT, te Pas AB, Kramer CM, et al. Intravenous immunoglobulin in neonates with rhesus hemolytic disease: a randomized controlled trial. Pediatr 2011; 127: 680-6.

\section{ENGLISH SUMMARY}

\section{Positive Coomb's test in newborns; causes and clinical consequences Summary of cases diagnosed in the Blood Bank in the years 2005 to 2012}

Thordis Kristinsdottir ${ }^{1}$ Sveinn Kjartansson ${ }^{2}$, Hildur Hardardottir ${ }^{1,3}$, Thorbjörn Jonsson ${ }^{4}$, Anna Margret Halldorsdottir

Introduction: Hemolytic disease of the fetus and newborn (HDFN) is caused by the destruction of fetal red blood cells due to red cell antibodies produced by the mother. HDFN can cause fetal hydrops during pregnancy or neonatal jaundice after birth. Direct Antiglobulin Test (DAT) detects antibodies bound to red cells and is a valuable test aiding in the diagnosis of HDFN. In Iceland DAT is routinely performed on cord blood or newborn blood samples if the mother is Rhesus $D$ negative or has non-A/B red cell alloantibodies. The aim of this study was to investigate the causes and consequences of positive DAT in newborns in Iceland over a period of eight years.

Material and methods: The study population was infants diagnosed with a positive DAT in the Blood Bank in Iceland in the years 2005-2012. Relevant data on the blood group and antibody status of mother and child, blood transfusion and DAT results were retrieved from the Blood Bank information system ProSang. Birth records provided information on birth weight, gestational age and phototherapy. Health records from the Children's Hospital provided information on the management and fate of the newborn.
Results: Over the study period 383 newborns had a positive DAT result at the Blood Bank. In $73.6 \%$ of cases the underlying cause was ABO blood group mismatch between mother and infant, in $20.4 \%$ of cases the mother had non-A/B red cell alloantibodies, in $3.9 \%$ both of above factors were present, while in $2.1 \%$ the cause was unclear. A total of 179 $(47.6 \%)$ children had neonatal jaundice that required treatment, of which 167 (93.3\%) only needed phototherapy. Eight infants required exchange transfusion, five of these had Rhesus antibodies and three $\mathrm{ABO}$ blood group mismatch.

Conclusion: $\mathrm{ABO}$ blood group mismatch between mother and child was the most common cause for a positive DAT in neonates in Iceland in the years 2005-2012. Almost half of the neonates required treatment but usually phototherapy was sufficient. Rarely, blood transfusion or exchange transfusion was necessary in severe cases of $A B O$ blood group mismatch or non-A/B red cell alloantibodies.

${ }^{1}$ Faculty of Medicine, University of Iceland, ${ }^{2}$ Children's Hospital of Landspitali, ${ }^{3}$ Department of Obstetrics and Gynecology, Landspitali, ${ }^{4}$ The Blood Bank, Landspitali.

Key words: Coombs test, Direct Antiglobulin Test (DAT), Hemolytic disease of the fetus and newborn (HDFN), ABO blood group mismatch, red cell alloantibodies, neonatal jaundice, exchange transfusion.

Correspondence: Anna Margrét Halldórsdóttir, annamha@landspitali.is 